\title{
Local Wisdom of Bugis Makassar Siri 'na Pacce from Millennials Glasses
}

\author{
Reski $\mathrm{P}^{1^{*}}$ Rahmat Nur ${ }^{1}$ Cucu Widayati ${ }^{1}$ \\ ${ }^{1}$ Department of Anthropology Sociology Education, Faculty of Teacher Training and Education, Lambung Mangkurat \\ University, Banjarmasin 70123, Indonesia \\ *Corresponding author.Email: reski@ulm.ac.id
}

\begin{abstract}
Good cultural values of a nation's civilization must preserve by passing down these cultural values to subsequent generations. Local wisdom of Bugis Makassar, Siri Na Pacce, is one of the many artistic benefits in Indonesia that is very important to build the character of the nation, especially the millennials, with a proportion of the population more significant than other generations. Local wisdom Siri Na Pacce is very laden with philosophical meaning in it. One of the values that are needed to be a cog in the behavior of today's millennial generation to be of good character. This research conducted to find out the meaning of Siri Na Pacce for Millennial generation nomads. This type of research uses a qualitative descriptive kind of approach. Siri 'is in the form of Alempureng (honest), Amaccangeng (Leardness), Assitinajang (Property), Agettengen (Tenacious) and Akkaresongen (effort) and pacce cultural values as a feeling of compassion or motivation to always care about others in this matter concerning strong solidarity in society that we must still maintain as our nature as social creatures. The results of the research show that even though they are far from their hometowns, the millennial generation of the Makassar Bugis tribe still adheres to the local wisdom of the Siri 'na pacce' in their daily lives nomads. They consider it essential as one form of social control in acting in society. The inheritance of local wisdom Siri 'na pacce, which ingrained becomes its footing for the Bugis Makassar millennial generation always to hold fast wherever they are, this identifies that Siri' na pacce also interpreted as the social identity of the Makassar Bugis tribe. Deep significance also reflected in positive values such as being able to foster motivation in work seen by millennial generations of local wisdom, making it even more stable to maintain it and practice it in everyday life nomads.
\end{abstract}

Keywords: Siri 'na pacce, Bugis Makassar, millennials.

\section{INTRODUCTION}

Indonesia is a vast nation with different potential. That diversity has become one of the prides of the Indonesian people, such as ethnicity, race, religion, and culture, which was inherited by the ancestors to be preserved and have high enough values as a tool to build the character of the Indonesian people themselves. It is time for the Indonesian people to return to national identity through socialization in terms of the meaning and strengthening of their noble cultural values. The effort is considered necessary because of the need to uncover the substantive meaning of the culture of local wisdom. Each tribe has cultural values that are respected, dignified, and peaceful. High cultural values become spirit embedded in and are applied in the form of behavior by every community as one of the things that attract attention is the local wisdom of the Makassar Bugis tribe, which are two of the four tribes in South Sulawesi. The tribe that also has a variety of local knowledge is also not immune from the onslaught of globalization at this time. The history of the Bugis is indeed very long, in historical texts such as the literary works of La Galigo and Lontara 'the beginnings of the Bugis civilization, the era of kingdoms, spiritual culture, customs and traditions and genealogies of aristocratic families. It shows that religion and customs must always maintain as a form of the heritage of the Bugis ancestors, who are undoubtedly full of positive values. Those who can uphold these principles are a reflection of a Bugis who descended from the upper world (to Manurung) to set an example in carrying social norms and rules [1]. Makassar is a Malay name for an ethnic group that inhabits the southern coast of Sulawesi. The Makassar tongue calls it Mangkassara 'meaning they are open. The term Bugis and Makassar is a term coined by the Dutch to divide these two ethnic groups [2]. The Makassar Bugis tribe is a tribe that likes to migrate. It can be seen that there is not a single island in Indonesia that is not inhabited by the Makassar Bugis Tribe. Wander means migration, but wander is a special type of migration with its own cultural connotation. According to Winstedt, Iskandar, and Purwadarminta, wandering came from the word rantau is a noun meaning lowland or watershed, so it is usually located close to-or part of the coastal area. village outside is generally carried out for various reasons, including expectations that will be found to live better in the village outside region, the conditions that are desirable during his stay in a foreign country [3]. It is within this wander that 
millennials are expected to still uphold the values of local wisdom so as not to be eroded by time.

Millennials are those born between 1980 and 2000. The generation that has the most proportion in Indonesia compared to other generations according to data from the Ministry of Women's Empowerment and Child Protection and BPS that around 50.36 percent of the population of productive age is basically a millennial generation (assuming: the dependency ratios for 2015 and 2017 are the same). With this proportion, it is indicated that this generation will be in control of the wheels of development, especially in the economic sector, which is expected to be able to bring the Indonesian people towards more advanced and dynamic development. The point of the millennial generation is big capital to realize the independence of the nation in all aspects. As a great capital for the development of a nation, the millennial generation is expected to have superior potential compared to the previous generation [4].

Having the most number of proportions would undoubtedly be a waste if this generation would not be able to contribute or even be a source of problems from various social issues in Indonesia, given the swift flow of globalization has dragged people, especially this millennial generation, into rapid change. Namely, the revolution era 4.0. A period marked by advances in the use of technology in various aspects of community life but at the same time will be a setback that traps in a variety of negative things or even leads to the moral degradation of society if not fortified with good character.

As a millennial writer, I feel that character is something urgent to talk about in Indonesia today. Various facts show the millennial generation who succeeded brilliantly, and on the other hand, they involved in the independent association. It sees from a variety of problems that emerge as a form of crisis of the character of millennials. Call it simple from honesty to complicated things which they describe in the way of deviant actions in society such as fraud, theft, promiscuity, drug use, misuse of technology (hoax spread, hate speech), pornography, porno-action and many more. From this, it appears there is a problem, namely the decline in the value of character in the millennial generation. And this certainly should not occur the nomads who are far from their hometown.

Mashadi Said and Andi Faisal Bakti argued that "a person can call a human being if he can position himself as a" tau "(human). This view means that one's words and behavior position oneself as a human with dignity or character [5]. From this opinion, the writer draws a common thread that good character will show that we are different human beings from animals. Humans know how to position themselves with words and behavior that fit their place. Discussing nature is a critical topic in building human resources. People who have substantial individual and social characteristics are those who have good character, morals, and character in their daily lives. Because whether we realize it or not, the wrong attitude will make the community even further from progress. A writer's conviction rests that a generation with style can make it easier for the Indonesian people to become a great nation. Remembering the words Bung Karno gave me ten young men, then I would shake the world, a statement of the belief that millennials or young people could be a milestone for world domination. There is also an expression if you want to destroy a nation then destroy its young generation. A feeling that shows the urgency of the younger generation, that the destruction of the younger generation is disastrous for the country. Therefore, it is essential to build the character of the millennial generation through local wisdom as a national identity.

Siri Na Pacce is one of the local wisdom of the Makassar Bugis tribe. The values in the philosophy of Siri 'na pacce as the principal capital of each nomad, are living books to uphold these values. As in the wise message: 'Kegasi sanree lopie kositu to tao sangereng' (Where the boat moored, that is where we put our minds). This sentence contains an ancestral message; each Bugis Makassar migrant must be able to adapt and socialize with his new environment. He adheres to the values of Siri 'na pesse as the main grip in acting and behaving while remaining adaptive and tolerant of local culture and customs. The tendency of the Bugis community reflects the advice of the ancestors wherever they are, does not mean allergic to change [6]. Because of this, the researcher is very interested in researching the local wisdom of Siri 'Na Pacce that there is a special meaning of this local wisdom so that it remains held by the millennial generation nomads.

\section{THEORETICAL FRAMEWORK 2.1 Local Wisdom}

Local Wisdom based on the belief that each community has specific strategies and techniques developed to carry out life according to its context. Cultural values deeply rooted in society that have educational value are what integrated into the world of education. Value-based education is needed to develop moral qualities, personalities, and community attitudes, which are increasingly eroded by the times [7]. In terms of its underlying philosophy, Wisdom can categorize in two aspects, namely: (a) ideas, thoughts, a reason which are abstract; and (b) local Wisdom in the form of particular matters, can be seen. The concept of a local wisdom system is rooted in domestic or traditional knowledge and management systems. Due to the close relationship with the environment and natural resources, local, conventional or native communities have gone through trials that have developed an understanding of the ecological system in which they live that has deemed to preserve natural resources and abandon activities deemed damaging to businesses [8].

\subsection{Siri 'Na Pacce}

According to Hamka said that "sometimes Siri 'na pacce are given the name of shame, and in the development of the Indonesian language they are named self-esteem [9]. Siri's understanding of the Makassar Bugis community, according to Abdullah, is not just a feeling of shame, but it concerns the most sensitive issues which are the soul and spirit in them, concerning the factor of dignity or selfesteem, reputation, and honor which must all be maintained and upheld. Siri 'places human existence on everything [10]. 
For the Bugis Makassar tribe, Siri na pacce / passe, which they hold as a philosophy of life and a source of inspiration for each of their behavior in social life. Even Siri 'na pacce considered as something sacred because of its sacredness, someone who is not able to maintain Siri' or lose Siri 'is considered as an animal (sippadai olo' olo'e). This, based on the fact in society that people who have no shame will be comfortable committing acts of violence that are not humane. In principle "Siri'mi Narituo" (only because Siri'we can survive), or "Siri'e mi ri onroang ri lino" (only Siri 'that we live in the world). As for people who die to defend their self-esteem, that tarnished is called "Mate ri siri'na" (die in Siri'). To die in defense of self-esteem is to be honored and commendable in the eyes of the Bugis Makassar people [11]. Siri 'has also been discussed and reviewed at the National Seminar organized by the Regional Police Command (KOMDAK) XVIII Sulselra in collaboration with Hasanuddin University, located in the pattern room of the Governor of South Sulawesi on July 11, 1977, until July 13, 1977, with the theme "Processing Siri Problems 'in South Sulawesi to increase national resilience in supporting national development. " The results of the seminar provide concepts and limitations on Siri '[9] including:

1. Siri's in the cultural system is a defense system of self-esteem, decency, and law and religion as one of the central values that influence and color the human mind, feelings, and wishes. As a cultural concept, it is a regulator in dynamizing structural functions in culture.

2. Siri 'in the social system, is to dynamize the balance of the existence of individual and community relations to maintain the continuity of kinship as an open social dynamic for role play (transmitting), changing forms (transforming), and reinterpreting by the development of national culture, so that Siri 'can help strengthen the upholding of the Indonesian nation's philosophy, Pancasila.

3. Siri's personality system is a concrete manifestation in the human mind that upholds honesty, balance, harmony, faith, and sincerity to maintain human dignity.

The concept of Siri's based on language understanding, terminology, and the results of the seminar can contribute ideas to the general public about the meaning and purpose of Siri's that deserve to believed, carried out, and maintained in daily life. From all of the sense of Siri ', it can be concluded that Siri' is a system of social, cultural and personality values which is a defense system of self-esteem and human dignity as individuals and members of society [11]. In the socio-cultural life of the Bugis- Makassar coastal community, the conception of siri' and pacce is reproduced, articulated, inherited, and expressed symbolically in a particular social context to result in changes and constituency [13].

Whereas in the language of understanding Pesse' (in Bugis language), or Pacce (in Makassar language) means" pain or pain, "but culturally interpreted as compassion, concern, the soul's call to help others. Makassar Bugis tribe, in general, emphasizes more on its cultural meaning, if Siri 'emphasizes the internal formation of a person, then pacce emphasizes more on the external fellow human beings. Between Siri 'and pacce' are intertwined in the living relationship of the Bugis Makassar tribe, complementing and complementing one another and cannot be separated from one another. The concept of Siri 'based on understanding language and terms can contribute ideas to the general public about the meaning and purpose of Siri's that deserves to believed, implemented, and maintained in daily life. Then it can be concluded that Siri 'is a system of social, cultural, and personality values, which are institutions of defense of human dignity and dignity as individuals and members of society [12].

Pacce can foster a sense of unity and national unity, promoting solidarity between humans to be willing to help someone who is experiencing difficulties. As an example of someone experiencing a disaster, it is clear that other people also felt the suffering experienced by his colleague and immediately at that time also took action to help him in the form of both material and nonmaterial. This feeling is an impetus towards solidarity in various ways towards those who are afflicted by misfortune [11].

The results of research conducted by Prof. Dr. H. A. Zainal Abidin Farid and friends revealed by Mannaho that Siri 'consists of two types [5], namely (1) Siri ripakasiri', implies contempt for fellow human beings who are outside the limits of humanity that is just and civilized and directly in public. reaction people insulted is have to take action by the actions of those who insult them. If he killed then his death is called mate ri santangi or mate rigollai or dies with pleasure or sweetness for defending his pride; (2) Siri 'masiri' implies a view of life that aims to maintain, improve or achieve an achievement that is carried out with all the might and effort of the person himself, for the sake of Siri's personal, family and group. Manifestation of this view of life, the Bugis Makassar community has a spirit of trying or working hard (Makkareso) to achieve high achievements or status in life, including migrating and studying; (3) Siri 'Na Pacce implies several central values of the culture of the people of South and West Sulawesi. According to Rahim [5] that the central benefits are:

1. Alempureng (honest)

Alempureng means honest; in this case, if it is associated with Siri, then it is a shame if we are not accurate in living life. As for the origin of honesty based on papaseng or the messages of old people in the Bugis tribe, there are evidence of goodness, namely: 1) narekko salai nangaui assalana (if he is guilty, he admits his mistake; 2) narekko rionroi sala, naddampengengngi or knows ripasalanna (if occupied liable, then is guilty did not disappoint), 3) narekko rirennuangngi de 'napacekowang (if expected, then he did not cheat; and 4) narekko' majjanciwi narupai jancinna (if promised, he kept).

2. Amaccangeng (Leardness)

In everyday conversation, the people of South and West Sulawesi often interpret acca (Bugis) or cara'de (Makassar together with smart or witty to be understood in a negative or positive sense. According to riolo, know that acca gave connotations that contain positive meanings. So that acca 
does not mean intelligent or witty but intellectual or intellectual, the intellectuals have four signs, namely 1) naitai riolona gau'e najeppuiwi munrinna (understanding the background of a problem and knowing the consequences, 2). Mappasitinaja, there are mappasiratang wenru '(piling words and fixing things), 3) saroi mase risilasanae pakkutana alena (humbling oneself by his selfesteem), 4) poadai ada matojo' enrengnge ada malemma (can speak words firmly, but meekly almighty.

3. Assitinajang (Property)

People can be trusted, starting with a firm conviction to place themselves as people who are adequately trusted and deserve trust. Properness is closely related to mental and physical abilities. Submission of one task or mandate must base on the appropriateness (assitinajang) and capacity. Ability emphasizes more on oversight for stakeholders.

4. Agettengen (Tenacious)

In everyday life, we also required to have courage. The actions of brave people of ten kinds and only one wrong, so the nine goodness. The reason is said to be one wrong because it quickly followed by death. However, the timid person will die too.

\section{Akkaresongen (effort)}

Business or work in bugis language stated in reso. People work called Tau Makkareso as manifestations of the value of honesty, the amount of an accident, cost of appropriateness, and the importance of their determination. 6. Village outside

Migration identified with the word wanderer who has been known and done long ago, where humans always move from one place to another. This transfer is done individually or in groups. But from the standpoint of sociology, looking at the term village outside contains six elements [3] including the following:

1. Leave the hometown,

2. By own will,

3. For a long period or not,

4. To find life, seek knowledge and seeking experience,

5. Usually to return home, and

6. Merantau is an entrenched social institution.

\section{METHOD}

This research uses the descriptive qualitative method. The technique of determining the informants using a purposive sampling technique is to determine the informant based on qualifications by the research topic. In this study, the informant who was the subject of the study was the Makassar Bugis Millennial Generation in Nomads. The criteria for determining informants are the millennial generation born in 1980 to 2000 , coming from the Bugis Makassar tribe, and currently migrating to work.

\section{RESULTS AND DISCUSSION}

Local Wisdom Siri Na Pacce is one of the local wisdom values of the Bugis Makassar tribe, which is full of philosophical meaning. One of the benefits that are needed to be a cog in the behavior of today's millennial generation to be of good character. In this connection, the meaning of the value of local wisdom Siri 'na Pacce' becomes an urgent matter to know. The definition shows a picture of what something is like in our glasses. By understanding the meaning of something well, we will be able to maximize our actions. That is how the millennial generation in the village outside who still upholds the value of siri 'na pacce' always to be actualized in their daily lives.

Based on the informant's explanation in this study, the Makassar Bugis tribe, which is also a millennial generation residing in village outside, knows very well the value of the local wisdom of siri 'na pacce.' They also uphold the local knowledge of Siri 'Na Pacee, even though it is far from his native land. As explained by a research informant who said that Siri 'is shame and pacce is a calling to maintain the culture of siri'. He further stated that it is essential to continue to hold the values of siri 'na pacce, because siri' should not only be interpreted as blood must be repaid with blood because such thoughts have experienced a shift from the previous meaning. The ultimate purpose of siri 'or masiri' is when we steal, when we don't respect others, kill and do other things that are not good. Also, other informants' interpretations mean siri 'na pacce as a reminder alarm for their behavior, every activity carried out should be through careful consideration so as not to have a destructive impact, especially in village outside, siri' na pacce must strictly adhere to in association.

Connected in the statement of the informants, that the value of local wisdom siri 'na pacce' is interpreted by the informants as social control for them in acting. Whatever they do must always hold siri 'in their daily lives if they want to remain in the corridor of good behavior. Something that shows that they also consider this value very positive for themselves.

Hirschi's theory reveals that humans are individuals who cannot obey rules and laws. Therefore social control is needed to make these individuals want to follow existing regulations and participate in increasing social power in society [14]. With the strong siri 'na pacce held by millennials nomads, it has become a social control tool that shows the success of the community and the surrounding environment to give meaning to the value of siri' na pacce to millennials to avoid deviations in society or lousy behavior by the norms in society. Travis Hirschi, in his book, revealed that the behavior that occurs in society occurs because of the failure of socialization in the community associated with commitment and awareness of the norms, rules, and existing rules. Deviations that occur and criminal behavior committed by someone considered as an impact of the failure of the community and the surrounding environment in forming social control, such as family, school, and so on [14].

In terms of working, the informant also claimed that he would work according to the mandated because otherwise, we would be considered as unprofessional and undoubtedly not responsible. Here, according to him, one aspect of the value of Siri that should exist in each of us migrated. Whereas pacce, according to him, is our form of consistency in actualizing Siri's values.

Siri na Pacce is also an informant who applies when working; they will work hard. It can seem that Siri 'for informants is Siri' masiri 'as revealed by Prof. Dr. H. A. 
Zainal Abidin Farid that siri masiri 'implies a view of life that aims to maintain, enhance or achieve an achievement that is carried out with all the might and effort of the person himself, for the sake of siri' personal, family and group. The manifestation of this view of life, the Bugis Makassar people have a spirit of trying or working hard (Makkareso) to maintain their self-esteem and also a high metabolism. A positive value in terms of increasing work motivation for immigrants from Makassar.

Furthermore, the research informant saw that siri was forced, not about paid lives. If it was still in a mild case, it could be resolved in another way with prior warning if it was involved in severe and outrageous matters as a millennial generation who understood the law, such a thing would be rushed to the realm of law because siri 'fixed prices for a Makassar Bugis tribe wherever located.

In connection with siri, 'this again confirms that we as humans must be ashamed if we do not have siri in the form of Alempureng (honest), Amaccangeng (Leardness), Assitinajang (Property), Agettengen (Tenacious) and Akkaresongen (effort). The five things that can underlie us to become personal characters amid the onslaught of change with various negative influences that can damage the future of millennial generation in addition to the value of Pacce culture as a motivation to always care about others in this case concerning strong solidarity in society that must always we keep it as our nature as a social creature.

It is crucial for the millennial generation of the Makassar Bugis tribe nomads to always uphold this siri 'na pacce in their daily lives because in their blood there is the blood of the Makassar Bugis tribe which, according to informants, the value of the siri' na pacce 'series is full of positive values for them. When they do not hold the amount of local wisdom, siri 'na pacce, the origin of their tribes questioned because this value has ingrained meat from generation to generation in South Sulawesi culture (Bugis Makassar). From these depictions, siri 'is also interpreted as the social identity of the Makassar Bugis tribe on the nomads who must hold firm because, in their bodies, the blood of the Makassar Bugis tribe flows. By upholding the local wisdom, siri 'na pacce' is what distinguishes the Makassar Bugis tribe from other tribes.

The inheritance of the local wisdom, siri 'na pacce, which is ingrained, has become a foothold for the millennial generation of Bugis Makassar always to hold fast wherever they are. The profound meaningfulness also reflected in the positive values seen by millennial generations about local wisdom, making it even more solid to maintain it and practice it daily.

Besides that, the exciting fact is that siri 'can be a motivation for millennials to migrate because they have to work hard nomads to become successful people so they can return to their homeland by bringing success and even becoming a siri' for this millennial generation. If returning to my hometown is not successful.

If someone does not own siri' $\mathrm{Na}$ Pacce as a view of life, it will be able to result in that person behaves selfishly because he does not have an element of social concern and only wants to win himself [15].
Humans in empirical reality, Siri's local wisdom 'Na Pacce' takes two forms in terms of; first that humans are creatures that have self-esteem and when self-esteem is gone there is no point in living and is considered to know (humans) and secondly that humans are social beings who have compassion for other creatures. From this, a process where the value of local wisdom is then maintained or strengthened.

If siri 'is a self-esteem bet, then that self-esteem must be raised through hard work, achievement, pioneering spirit, and success-oriented attitude. Self-esteem is boosted by the support of a sense of Pesse (Bugis) or Pacce (Makassar), which is solidarity with others as social participation because the self-esteem assessment comes from the social environment. Pesse is compassion to see others who experience suffering or inner pressure for the actions of others and the like. Siri 'and Pacce are two moral attitudes that maintain stability and have a harmonious dimension so that the social order or Pangadereng (adat core adat) runs dynamically. Departing from Abu Hamid's theory, the Indonesian people have rightly returned to their identity through the reinterpretation and reconstruction of noble cultural values. Reinterpretation of the meaning of siri 'for revitalization is useful for the development of civilization in a global society because it functions as a motivator, social control, sense of responsibility and social dynamism [12]. Through millennial generation as a milestone to advance the nation, it fits for the value of the culture of local wisdom Siri $\mathrm{Na}$ Pacce can prepare qualified human resources ready to compete in the global era, but still has ethical character values. The values of Siri' na pacce's local wisdom culture can be implemented for millennials in various ways, primarily integrating them into the daily lives of millennials. Maintaining self-esteem here can be actualized in social life in society to be superior, competitive, and even embarrassed when unable to do the best or embarrassed when involved in things that deviate. Meaning of the word siri 'which illustrates that there is nothing more valuable than siri.' Siri 'is what makes humans as whole people even when siri' is tarnished. It is better to die because life is worthless without siri 'yet it is no different from animals.

\section{CONCLUSION}

The meaning of siri 'na pacce for nomads millennials is as a form of social control in behaving in society. The inheritance of local wisdom siri' na pacce', which ingrained becomes its footing for the Bugis Makassar millennial generation always to hold fast wherever they are this identifies that siri' na pacce is also interpreted as the social identity of the Makassar Bugis tribe. Deep significance is also reflected in positive values such as being able to foster motivation in work seen by millennial generations of local wisdom, making it even more stable to maintain it and practice it in everyday life in village outside.

Ethical, cultural values of a nation's civilization must continue to be preserved by passing down these cultural values to subsequent generations. Local wisdom of Bugis Makassar, Siri Na Pacce is one of the many artistic benefits 
in Indonesia that is very important to build the character of the nation, the especially millennial generation, with a more significant proportion of the population. The philosophy that is historically owned by the Makassar Bugis tribe, but this philosophy can be applied nationally as a handle in everyday life.

\section{ACKNOWLEDGMENT}

Thanks to Faculty of Teaching Training and Education Science who has supported me for joining the international conference. Thanks to my colleagues in the sociology-anthropology department for being a good colleague. Thanks to my parents who always support me.

Alauddin Makassar," Tahdis, vol. volume 7 Nomor 2 Tahun 2016, 2016.

[10] S. Beddu, "Eksplorasi Kearifan Budaya Lokal Sebagai Landasan Perumusan Tatanan Perumahan dan Permukiman Masyarakat Makassar," in Prosiding Temul Ilmiah IPLBI 2014.

[11] R. d. A. U. Darwis, "Implikasi falsafah Siri na Pacce Pada Masyarakat Suku Makassar Di Kabupaten Gowa. Fakultas Syariah dan Ekonomi Islam IAIN Sultan Amai Gorontalo," el Harakah, vol. Vol.14 No.2 Tahun 2012 , 2012.

[12] M. Rusli, "Impelementasi Nilai Siri' Napacce Dan Agama Di Tanah Rantau; Potret Suku BugisMakassar Di Kota Gorontalo," Jurnal al-Asas, Vols. Vol. II, No. 2, 2016.

[13] A. d. S. Ramli, "Kondobuleng Folk Theater : Representation of Socio-cultural Identity of BugisMakassar Coastal Communities," The Journal of Educational Development JED, vol. 6 (3) 2018, pp. 302 - 311, 2018.

[14] Khadijah, "Agama dan Budaya malu sebagi kontrol sosial terhadap perilaku koruptif," Sosial Budaya, vol. Vol 15 No 2, 2018.

[15] M. I. R. d. S. Prasetyaningrum, "Nilai Budaya Siri' na pacce dan Perilaku Korupsi," Jurnal Indigenous, vol. Vol 9 (2), pp. hlm. 70-71, 2015.

[16] T. d. .. Riswandi, "Pengaruh Nilai Budaya Siri' na pacce Dalam Pelayanan Publik Di Kabupaten Bone," Pleno Jure, vol. Vol. 9 (2) .

[9] S. Maghfirah, "Siri' na pacce Dalam Suku Makassar Perspektif Al-Qur'An Dan Hadis. Uin 